\title{
Analysis of the airborne mercury and particulate arsenic levels close to an abandoned waste dump and buildings of a mercury mine and the potential risk of atmospheric pollution
}

\author{
Hector Garcia Gonzalez ${ }^{1}$ (D) - Efren García-Ordiales ${ }^{2}$ (D) - Rafael Rodriguez Diez ${ }^{3}$ (D)
}

Received: 18 October 2021 / Accepted: 24 January 2022

Published online: 01 March 2022

(c) The Author(s) 2022 OPEN

\begin{abstract}
The project SUBproducts4LIFE is a research project financed by the European Union within the framework of the LIFE programme which proposes to demonstrate innovative circular economy concepts by the reuse of industrial subproducts/waste (coal ash and gypsum from coal power plants, blast furnace slag and steelmaking slag from steel factories) for the remediation at a real scale of contaminated soils and brownfield areas related to $\mathrm{Hg}$ mining. The area it is developing includes the waste dumps and demolition waste of the metallurgical plant of the abandoned mercury mine La Soterraña in Asturias, Northern Spain. Before this restoration research project takes place, this paper aims to evaluate airborne mercury and arsenic levels in land strongly contaminated with arsenic and mercury. The goal is to evaluate the air quality and compare it with international literature under reference levels. The study sampled gaseous mercury with a high-resolution direct reading device (LUMEX RA-915) and arsenic and mercury particulates with an IOM sampler, Casella personal pump, analyzed in the laboratory, to ensure the Health and Safety of workers, visitors and pedestrians walking near the mine and near the villages. The study concludes that As and $\mathrm{Hg}$ levels in the air are below $1 \mu \mathrm{g} / \mathrm{m}^{3}$ for the general public and villages near the mine. For works in the rubble area in the mine, it is recommended that workers use personal protective equipment and control measures are used to keep arsenic and mercury levels as low as technically possible.

\section{Article Highlights}

- Gaseous $\mathrm{Hg}$ and airborne $\mathrm{Hg}$ and As particulates are measured in a strongly contaminated mercury mining and metallurgy site.

- High concentration of gaseous $\mathrm{Hg}$ is present in the strongly contaminated soils; therefore protective measures must be adopted for workers.

- Apart from an area with demolition rubble of a metallurgical plant, airborne $\mathrm{Hg}$-As contamination is not harmful to workers or the general public.
\end{abstract}

Keywords Arsenic $\cdot$ Mercury $\cdot$ Abandoned mines $\cdot$ Airborne $\cdot$ Spoil tip

\footnotetext{
Hector Garcia Gonzalez, hectorg@ins.es; Efren García-Ordiales, garciaefren@uniovi.es; Rafael Rodriguez Diez, rrodrifer@uniovi.es ${ }^{1}$ Instituto Nacional de Silicosis, Oviedo, Spain. ${ }^{2}$ Mining, Energy and Materials Engineering School, University of Oviedo, Oviedo, Spain. ${ }^{3}$ Department of Exploitation and Exploration of Mines, University of Oviedo, Oviedo School of Mines, Independencia 13, 33004 Oviedo, Spain.
} 


\section{Introduction}

\subsection{La Soterraña mine}

Abandoned mines can create significant environmental and social problems, there are thousands of examples worldwide. Before environmental regulations, mining lands were left without any remediation plans. More than a million abandoned mines are estimated to exist around the world [1]. There are several problems, for example, heavy metals, acid mine drainage, soil and water contamination, etc.

Mercury is a metal with an essential presence in the industry between the 16th and 20th Centuries, having been used in many sectors, starting with the metallurgical separation of silver and gold, passing through clinical applications (treatment for syphilis; disinfectant of wounds, etc.), measurement devices (thermometers, barometers) to many others, still well known in modern times, such as chlor-alkali electrolysis, lighting, and dental amalgams, amongst others [2].

In Spain, mercury mining was very productive during the sixties and seventies [3]. In Asturias, there were more than 20 mercury exploitations; the main two were Soterraña in Pola de Lena and La Peña-El Terronal in Mieres [4]. These mines were abandoned without any restoration plans, and now there is a health problem for the region. Nowadays, the Soterraña mine is one of the most contaminated sites in Europe [5].

The Soterraña mine is located in Pola de Lena, $30 \mathrm{~km}$ south of Oviedo. The mine geology is a low-temperature hydrothermal epigenetic deposit. The predominant minerals are cinnabar (mercury sulfide), realgar (arsenic sulfide), and in smaller proportion oropiment (another arsenic sulfide). There are also arsenopyrite, marcasite, and pyrite hosted in fractured limestones and shales [6]. The gangue is composed of carbonates, quartz, and argillaceous minerals (kaolinite and dickite) [7].

\subsection{Effects of arsenic and mercury on the human health}

The effects of arsenic on health are very well studied; in 1980, the International Agency for Research on Cancer (IARC) concluded that arsenic was a human lung carcinogen [8]. It produces respiratory diseases in the lungs. It causes neurotoxic effects and skin lesions. There is a clear dose-response relationship between airborne arsenic and lung cancer [9]; Arsenic also increases the risk of tumours of the bladder, lungs, kidneys, and liver. Exposure can develop the vascular diseases, including stroke, ischemic heart disease, and peripheral vascular disease [10]. However, sometimes it is problematic to attribute these diseases to arsenic exposure due to the existence of nonspecific symptoms [11].

In the same way, mercury effects are also well studied; according to the WHO (World Health Organization), the inhalation of mercury can produce harmful effects on the nervous, immune, and digestive systems, lungs, and kidneys, and may be fatal. Some exposure symptoms include memory loss, neuromuscular effects, headaches, cognitive and motor dysfunction, tremors, and insomnia. In extremely high concentrations, some forms of mercury have caused several types of tumours in rats and mice. [12, 13]. The most toxic form is the methylmercury and metallic mercury vapour; exposure to high levels can permanently damage the brain, kidneys, and developing fetus. Other effects from mercury are abdominal pain, inflammatory bowel disease, ulcers, bloody diarrhoea, destruction of intestinal flora, endocrine system affections and reduced fertility. Mercury is bioaccumulative in the body, mainly in the liver, brain, and kidneys [14]. Nowadays, the Minamata Convention on mercury (http://www.mercuryconvention. org/) is an international program aimed to ban the trade and usage of mercury all over the world.

The data published in international treatizes and journals essentially notes that the main problem related to mercury in decommissioned mines is the presence of mercury vapour in the atmosphere because of the polluted waste material stored in these areas [15]. The presence of mercury in the spoil heaps and soils in the surroundings of these areas also represents a risk: the gaseous mercury released during mine works and from the waste material suffers dry- or wet deposition not far from the source, producing the contamination of the soils; in the same way, the release in uncontrolled conditions of waste coming from the demolition of structures can also create soil pollution.

\subsection{The SUBproducts4LIFE project}

The project SUBproducts4LIFE is a project co-funded by the European Union within the program LIFE [11]. The project SUBproducts4LIFE proposes to demonstrate innovative circular economy concepts by the reuse of industrial subproducts/waste (coal ash and gypsum from coal power plants, and blast furnace slag and steelmaking slag from steel factories) for the remediation at a real scale of contaminated soils and brownfield areas related to $\mathrm{Hg}$ mining. The area it is developing includes the waste dumps and demolition waste of the metallurgical plant of the abandoned mercury mine La Soterraña in Asturias, Northern Spain [12].

Intending to fulfil all the targets, some specialist organizations started to work together on the project. The 
University of Oviedo (UNIOVI) coordinates the project and leads the investigation; the Instituto Asturiano de Prevención de Riesgos Laborales (IAPRL) is in charge of the health and safety issues. Small and medium-sized companies also participate, Bisofera Consultoría Medioambiental SL (BIOSFERA) studies the environmental impact of the project, Recuperación y Renovación SL (R\&R) is responsible for the technical part, Global Service SL (GSERVICE) is responsible for all the civil works. Likewise, large companies such as Hidroeléctrica del Cantábrico SA (EDP), which contributes with the ashes from the thermal power plant, and the company Escorias y Derivados SA (EDERSA), which supplies the slag from the blast furnaces of the regional steel industry (Arcelor Mittal), and lastly, the Instituto Nacional de Silicosis (INS) started its collaboration once the project had commenced.

The main objective is to increase the value chain of four subproducts from different industrial processes promoting industrial symbiosis between active industries with high waste/subproducts production levels (power plant and steel factories) and contaminated sites (abandoned mines including metallurgical plants).

Nevertheless, another relevant objective is to improve the environmental conditions at the site and diminish its polluting potential by:

(a) reducing the mobility of arsenic and mercury in the soil

(b) reducing these elements in the leachate water and

(c) preventing the contamination of the rainwater.

Mercury-enriched waste dumps contribute to the global mercury pool over time [15], and this project can help to reduce these emissions in the near future, giving an important circular mining value to the recovery of this area.

On the other hand, all the works necessary to implement the project must be carried out under complex conditions due to the high levels of arsenic and mercury contamination, which means it is important to follow the Safety and Health Prevention and Assessment of Occupational Hazards protocols.

\subsection{The study of the atmospheric contamination with As and $\mathrm{Hg}$}

In this context, it is of utmost importance to carry out mercury and arsenic measurements at the mine yard and in the surrounding areas.

There are several types of research about surface water and soil contamination in the site $[3,16,17]$, but the air pollution in the area was not well studied, Loredo et al. (2006), studied the atmospheric mercury levels in la Soterraña with a portable $\mathrm{Hg}$ analyser (Mercury Tracker-300) with a detection limit of $0.1 \mu \mathrm{g} / \mathrm{m}^{3}$ and obtained values from the detection limit to $2.3 \mu \mathrm{g} / \mathrm{m}^{3}$ on the old chimney at $20 \mathrm{~cm}$ above the ground level [7], but since then no other studies about airborne pollution have been found.

This research will evaluate the airborne arsenic and mercury levels previous to any land movement or work in the Soterraña mine with the main target being to ensure the Health \& Safety to the workers, the partners involved in the project, and the general public.

From a Health and Safety point of view, it must be taken into account that the Spanish law establishes that the risk must be evaluated; based on this evaluation, preventive measures, personal protective equipment (PPE), training of the workers... etc., must be taken into account. Arsenic and mercury levels in the air must be evaluated for the preparatory works before starting the movement of contaminated waste and rubble; This study will be completed later with more measurements when the work will be completed.

From the point of view of the project, it is crucial because one of the objectives of SUBproducts4LIFE is to facilitate visits to the facilities to see their progress, the works carried out, and the results obtained; The stakeholders are very varied, ranging from students in training to companies interested in environmental recovery or residents of the area (the commencement of the project was announced in a meeting with residents at the mine facilities); It is evident that these visits must be carried out in the safest conditions.

From a general population point of view, the abandoned mine and facilities are close to the Soterraña village and near Muñon Cimero village. As they are the nearest villages, they have suffered high contamination from mercury and arsenic. But the adverse effects affect other kinds of citizens. For example, the road close to La Soterraña mine is an important cycling route for professional and amateur cyclists; every day dozens of cyclists and hikers pass near the mine in the road to the peak Alto del Cordal. Also the area has a potential for other uses like rural tourism. For these reasons, studying the potential adverse effects on the environment is of the most importance. Soils and water have already been studied before, but no studies relating to the atmosphere have been conducted recently.

This study analyzed gaseous mercury with a high-resolution direct reading device and arsenic and mercury particulates with the Inductively Coupled Plasma Mass Spectrometry (ICP-MS) technique. There are no previous studies about particulate airborne arsenic levels in Soterraña, even though it is the contaminant most frequently found in the soil. 
Table 1 Inhalation reference values for elemental mercury vapour ( adapted from US EPA, 2009)

\begin{tabular}{lr}
\hline Reference value type/Name & $\begin{array}{l}\text { Reference } \\
\text { value (ng/ } \\
\mathrm{m}^{3} \text { ) }\end{array}$ \\
\hline AEGL-3 (1-h) & $8,900,000$ \\
AEGL-2 (1-h) & $1,700,000$ \\
NIOSH ceiling (10-min) & 100,000 \\
NIOSH REL (10-h TWA) & 50,000 \\
CaIEPA REL (1-h) & 600 \\
Chronic-EPA RfC & 300 \\
\hline
\end{tabular}

\section{Arsenic and mercury airborne regulations}

\subsection{Mercury}

Due to the expressed concerns, the concentrations of mercury in the atmosphere are regulated by several national and international entities. Table 1 shows the most important inhalation reference values for elemental mercury vapour, compiled by Hagan et al. [18] and adapted from US EPA (2009) [19].

$A E G L$ values are developed for a rare, "once-in-a-lifetime" exposure scenario and are designed for the general public. The AEGL-2 values, if exceeded, can cause irreversible effects or impair the ability to escape, whereas AEGL-3 values approach the threshold for lethality. The NIOSH Ceiling values are "levels of exposure that should not be exceeded at any time" (NIOSH, 2006) [20]. The NIOSH REL is a value that should not be exceeded during a $10 \mathrm{~h}$ workday based on a $40 \mathrm{~h}$ workweek. The CalEPA Acute (1-h) REL is "the concentration level at or below which no adverse health effects are anticipated for a specified exposure duration" and "are designed to protect the most sensitive individuals in the population by the inclusion of margins of safety" (OEHHA, 2008) [21]. The US EPA RfC was developed for chronic exposure scenarios and is "an estimate (with uncertainty spanning perhaps an order of magnitude) of a continuous inhalation exposure to the human population (including sensitive subgroups) that is likely to be without an appreciable risk of deleterious effects during a lifetime" (US EPA, 1995b)[22].

In Spain, legal requirements at work are provided by the Instituto Nacional de Seguridad e Higiene en el Trabajo (INSST). For mercury the Threshold limit value-timeweighted average (TLV-TWA): average exposure based on $8 \mathrm{~h} /$ day, $40 \mathrm{~h} /$ week work schedule for each substance is $0.02 \mathrm{mg} / \mathrm{m}^{3}$ [23]. For environmental values, $10 \%$ of the TLV-TWA values, $2 \mu \mathrm{g} / \mathrm{m}^{3}$ are usually considered, taking into account the WHO guidelines of $1 \mu \mathrm{g} / \mathrm{m}^{3}$ annual average [24].

\subsection{Arsenic}

The arsenic air levels Threshold limit value, time-weighted average (TLV-TWA): average exposure based on an $8 \mathrm{~h} /$ day, $40 \mathrm{~h} /$ week work schedule is $10 \mu \mathrm{g} / \mathrm{m}^{3}$ [23], for environmental values the Spanish Royal Decree 102/2011 established annual average of $6 \mathrm{ng} / \mathrm{m}^{3}$ [25] and the WHO considers that a safe level cannot be established [24].

Note that (TLV-TWA) values are considered for measurements in the worker "breathing zone" (space around the face of the worker from which the worker regularly draws in breathing air to breathe, defined as a hemisphere with a radius of $30 \mathrm{~cm}$ extending in front of the face of the worker).

\section{Material and methods}

\subsection{Gaseous mercury surveys}

Gaseous mercury surveys are based on measuring gaseous mercury concentrations in the atmosphere using portable analytical devices. The analytical device measures the $\mathrm{Hg}$ concentrations at fixed time intervals and stores the results in an internal data logger. The geographical position is recorded and stored in a GPS device so that it is possible to assign a coordinates position for each of the analytical data recorded.

The equipment used was a LUMEX RA-915 (Fig. 1) with an analytical gaseous $\mathrm{Hg}$ range of $1-100.000 \mathrm{ng} / \mathrm{m}^{3}$. The equipment sampled $10 \mathrm{l} / \mathrm{min}$ of air and reported one

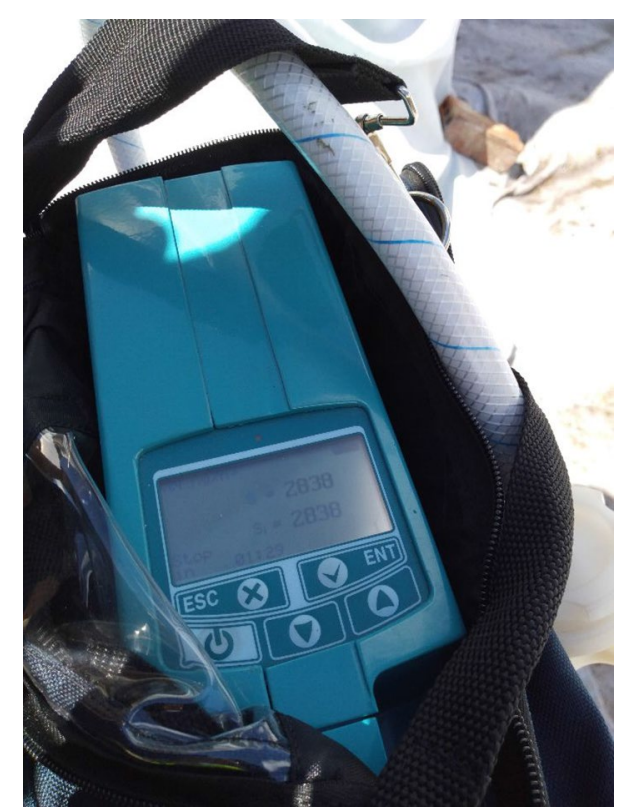

Fig. 1 LUMEX RA-915 mercury analyser

\section{SN Applied Sciences}



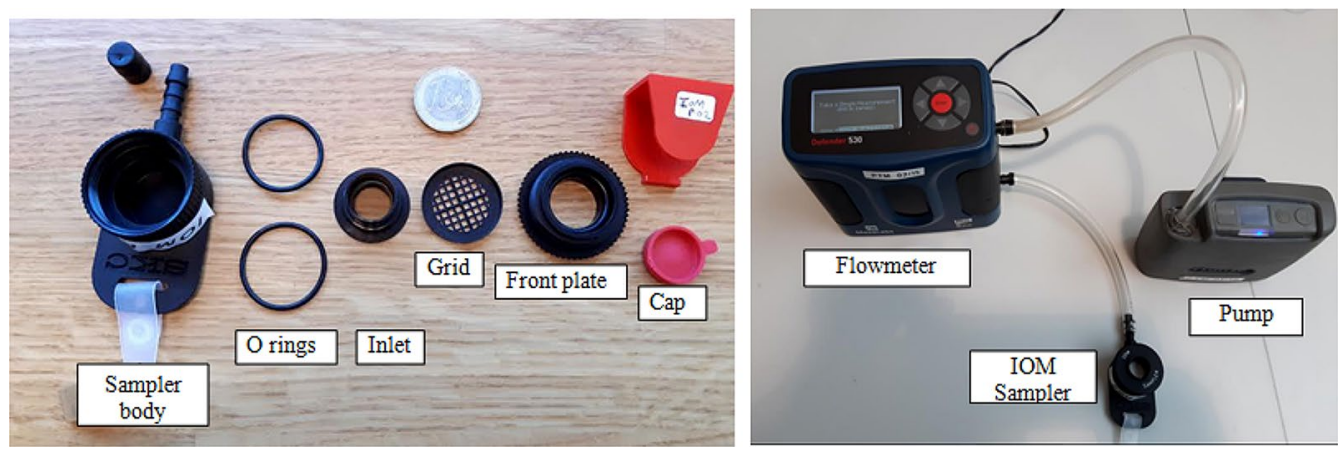

Fig. 2 IOM sampler parts and pump calibration to $2.0 \mathrm{I} / \mathrm{min}$

analysis each $1 \mathrm{~s}$ and stored these measurements in the internal data logger. This equipment has been widely used in the scientific literature and by reference organizations to monitor gaseous mercury in different conditions and environments. Together with the $\mathrm{Hg}$ analyser, a GPS Garmin Etrex Touch 35 was used. The GPS was programmed to record positions every second to match this data with the Hg measurements. LUMEX RA-915 only analyses gaseous mercury, neglecting the $\mathrm{Hg}$ particulates which are removed by means of a filter at the entrance of the equipment.

\subsection{Arsenic and mercury particulate air surveys}

The sampler selected in this study is the IOM sampler. The IOM sampling head is the most commonly used in Europe for the inhalable fraction. The inhalable fraction corresponds to the mass of particles whose aerodynamic diameter is between 0 and $100 \mu \mathrm{m}$ [26], fraction used for airborne metal sampling. According to the Health and Safety Executive (HSE), the IOM sampler is the most accurate method of sampling the inhalable aerosol because it is the most accurate under the broadest range of workplace conditions [27].

The diagram below shows the parts (Fig. 2). The sampling head can be loaded with $25 \mathrm{~mm}$ cellulose filters; the sampler operates at $2.0 \mathrm{l} / \mathrm{min}$.

The sampler flow rate was checked before each sampling using a calibrated MesaLabs Bios DryCal Defender 530 and adjusted if necessary so that it was within $0.010 \mathrm{l} /$ min of the target value. It was also checked after the sample was taken.

The pump selected was the APEX2; it is a personal air sampling pump typically used to take airborne materials or toxic contaminants samples. The pump is designed to provide a stable, controlled flow rate of approximately 0.5 to $5 \mathrm{l} / \mathrm{min}$ such that a known volume of air is passed through a passive sampling head and filter medium [28]. It is certified with Atex I M1, it is ideal for mines measurements. All the pumps used were well-maintained to avoid pulsations and fluctuations in the flow rate.

Airborne materials are collected into a Mixed Cellulose Ester (MCE) membrane filter substrate. Blank filters were used for the analytical process in the lab.

Samples were analyzed with Inductively Coupled Plasma Mass Spectrometry (ICP-MS) ICP-MS Agilent 7500 $c x$. The method is typically used in environmental monitoring and other activities for sampling arsenic particulates or other metals in the air, and is similar to the OSHA ID 1006 or NIOSH 7300.

\subsection{Methods}

The gaseous mercury surveys with the direct reading device were carried out in different climatic conditions to evaluate the influence of parameters such as temperature on the potential release of $\mathrm{Hg}$ in the mining area. In total, four surveys were made in the Soterraña Mine. In each survey, 22 control points were monitored in detail to evaluate the areas of greatest risk due to the presence of gaseous mercury over time. All the measurements were carried out at $1.5 \mathrm{~m}$ above ground level. It is the recommended height for airborne environmental values [29]. Figure 3 shows each control point overlaying on aerial photography of the study area.

Particulate arsenic and mercury airborne analyzed with analytical methods, three areas in the mine were selected (Fig. 4) (the most contaminated parts of the mine's surroundings), the soil's arsenic and mercury contamination levels were obtained from previous studies from the Universidad de Oviedo and the regional Government Environment Authority.

The first area is where the demolition debris from the old metallurgy furnace is located (number 10) Figs. 3 and 4; The second area is where the metallurgy furnace was located originally during the mine production in the sixties (number 11); the third area is the furnace slag heap (number 21) (The place where non-interest materials were 


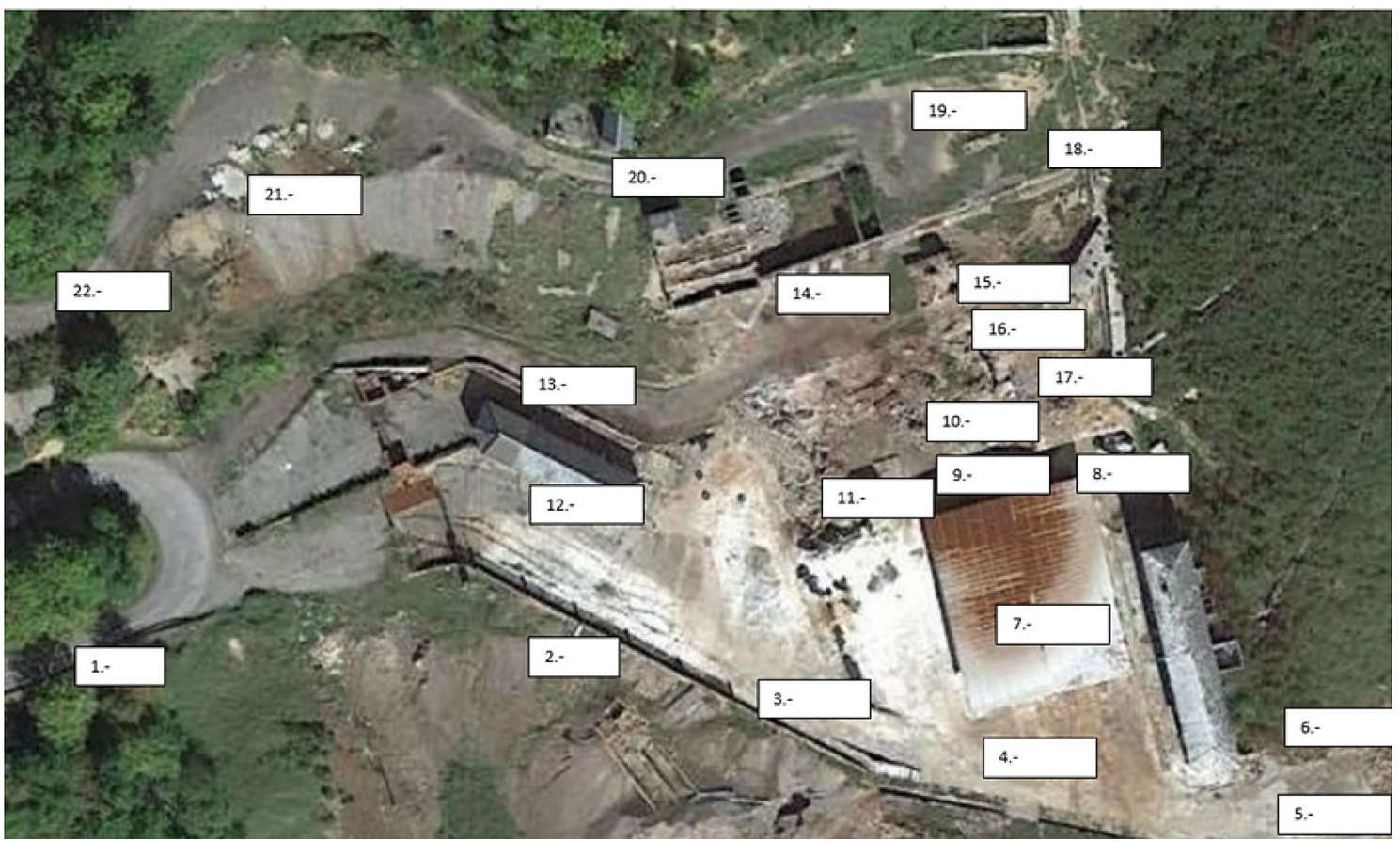

Fig. 3 Areas of study in the Soterraña mine, Pola de Lena (Asturias)
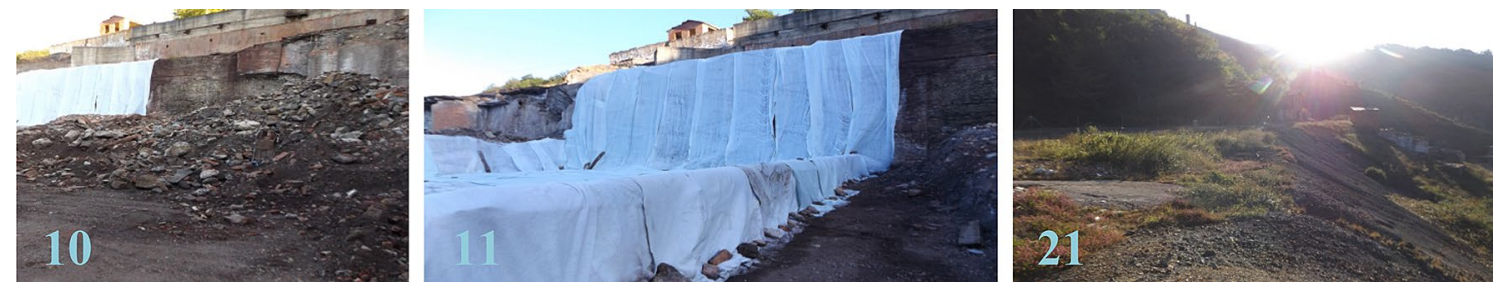

Fig. 4 Main areas of study in the Soterraña mine, Pola de Lena (Asturias)

located after treatment in the furnace). These three areas were selected in the project SUBproducts4life to start the treatment and the research, the chimneys are not in the scope of Subproducts4life project.

The IOM sampler was located close to the floor (at $20 \mathrm{~cm}$ above the ground level). The main idea was to position the sampler as close as possible to the floor; as in a worst-case scenario.

The first sampling was carried out on a sunny day in August, which would probably be the worst-case scenario if we take into account that rain is widespread in this area [7]. The selected sampling time was $10 \mathrm{~h}$ to ensure the wide representativeness of the samples. Another sample was taken in September on a windy day to confirm the results. The laboratory's analytical method consists of passing the sample through microwave-assisted acid digestion (with HNO3) in a closed Polytetrafluoroethylene (PTFE) container. After diluting it, it is introduced in argon plasma, where the energy transfer process causes desolvation, atomization, and ionization. The ions are extracted at an interface by pressure differences. At that point, some polyatomic interferences are removed in a pressurized collision cell with helium, and the ions are separated based on their mass/charge ratio by a quadrupole. The transmitted signal is detected in an electron photomultiplier tube.

\section{Results and discussion}

\subsection{Gaseous mercury}

Gaseous mercury measurements are recorded in Table 2, the temperature, soil temperature and location are also recorded.

Considering the results from survey 1 , only the control points 9 and 10 can be problematic. The presence of rubble from ancient metallurgy is the cause of these high gaseous mercury values. In this zone, during hot days,

\section{SN Applied Sciences}


Table 2 Contamination levels in the air

\begin{tabular}{|c|c|c|c|c|c|}
\hline & Date & $\begin{array}{l}\text { Survey } 1 \\
10 / 08 / 2020\end{array}$ & $\begin{array}{l}\text { Survey } 2 \\
19 / 08 / 2020\end{array}$ & $\begin{array}{l}\text { Survey } 3 \\
10 / 09 / 2020\end{array}$ & $\begin{array}{l}\text { Survey } 4 \\
29 / 10 / 2020\end{array}$ \\
\hline & Temperature & $29^{\circ} \mathrm{C}$ & $30^{\circ} \mathrm{C}$ & $15^{\circ} \mathrm{C}$ & $5^{\circ} \mathrm{C}$ \\
\hline & Soil temperature & $21^{\circ} \mathrm{C}$ & $23^{\circ} \mathrm{C}$ & $10^{\circ} \mathrm{C}$ & $4^{\circ} \mathrm{C}$ \\
\hline & Concentration & $\mathrm{ng} / \mathrm{m}^{3}$ & $\mathrm{ng} / \mathrm{m}^{3}$ & $\mathrm{ng} / \mathrm{m}^{3}$ & $\mathrm{ng} / \mathrm{m}^{3}$ \\
\hline & Location & & & & \\
\hline 1 & High road & 32 & 10 & 200 & 67 \\
\hline 2 & External wall & 385 & 250 & 425 & 2379 \\
\hline 3 & Store & 339 & 1750 & 950 & 927 \\
\hline 4 & Trench & 741,5 & 450 & 350 & 761 \\
\hline 5 & Yard extension & 360 & 75 & 1900 & 600 \\
\hline 6 & Yard & 52.5 & 275 & 25 & 11 \\
\hline 7 & Shed & 295.5 & 800 & 3000 & 223 \\
\hline 8 & Shed corner & 2317 & 1500 & 2000 & 2829 \\
\hline 9 & Botton rubble furnace & $20,866.5$ & 15,000 & 30,000 & 5524 \\
\hline 10 & Rubble (Metallurgy furnace debris) & $58,487.5$ & 50,000 & 50,000 & 6855 \\
\hline 11 & Internal wall & 3305 & 17,500 & 17,500 & 15,826 \\
\hline 12 & Office & 437 & 250 & 800 & 1437 \\
\hline 13 & First level & 231 & 700 & 175 & 872 \\
\hline 14 & First level wall & N.D. & 800 & 4000 & 3238 \\
\hline 15 & First level rubble & 3855 & 4500 & 2500 & 4936 \\
\hline 16 & First level rubble2 & N.D. & 4500 & 4000 & 4097 \\
\hline 17 & First level chimmeney & 767.5 & 6000 & 30,000 & 10,261 \\
\hline 18 & Second level staris & 194 & 650 & 900 & 702 \\
\hline 19 & Second level ditch & 156 & 500 & 1100 & 563 \\
\hline 20 & Second level transformer & 253 & 1000 & 1200 & 1005 \\
\hline 21 & Furnace slap heap & 455 & 350 & 1400 & 263 \\
\hline 22 & Second level entrance & 56 & 30 & 300 & 31 \\
\hline
\end{tabular}

N.D. not determined significant $\mathrm{Hg}$ concentrations can be released from the rubble.

In surveis 2 , the control points $(9,10,11$ and 17) close to the rubble from ancient metallurgy were the problematic points for the gaseous mercury concentrations. Thus, during hot days it is recommended that workers are not exposed to this area for extended periods.

In survey 3, the control points close to the rubble from ancient metallurgy were the problematic points in the gaseous mercury concentrations.

In survey 4, looking at the results and weather conditions, the release of $\mathrm{Hg}$ decreases significantly during cold days. At the control points close to the rubble from ancient metallurgy, the values detected were the highest but not very problematic regarding worker protection.

Considering all the results, the rubble area (points 9, 10 and 17) is the most problematic because the TLV-TWA of $20 \mu \mathrm{g} / \mathrm{m}^{3}$ was reported during the summer. It is highly recommended that the site be fenced in and that there should be no unauthorized entry without PPE (personal protective equipment). The second area corresponds to the potential to reach the environmental values, points 7 , $8,11,14,15$, and 16 ; this area must be closed to the general public, and PPE should be used by authorized personnel. The third area, with low concentration levels $(<10 \%$ TLV-TWA), could be open to the general public without PPE.

Regarding soils mercury levels in industrial sites, the International Legislation established the intervention level at $30 \mathrm{ppm}$ [30], and $15 \mathrm{ppm}$ for non-industrial activities, in Asturias the regional legislation from March 202014 [31] established a limit of $100 \mathrm{ppm}$ for industrial activities and $10 \mathrm{ppm}$ for non-industrial activities. As it is shown in Table 3, the Soterraña soils are very contaminated, mainly by the debris from the metallurgy furnace (points 10 and 11 ) and the furnace slag heap (point 21).

It is recommended that the site be fenced off, with at least three zones. In zone 1, the rubble area, points 9, 10 and 17, it is the most problematic area (it is highly recommended the area be fenced off and that any unauthorized 
Table 3 Contamination levels in soil in Soterraña (nearest point)

\begin{tabular}{llll}
\hline & Concentration & Soils & \\
\cline { 3 - 4 } & Location & Mercury $(\mathrm{ppm})$ & Arsenic (ppm) \\
\hline 1 & High road & 9 & 195 \\
2 & External wall & 74 & 764 \\
3 & Store & 100 & 1182 \\
4 & Trench & 15 & 210 \\
5 & Yard extension & 100 & 2907 \\
10 & Rubble (Metallurgy & $34,691[32]$ & $54,801[32]$ \\
& furnace debris) & & \\
21 & Furnace slap heap & $10,800[33]$ & $1330[33]$ \\
22 & Second level entrance & 60 & 1074 \\
\hline
\end{tabular}

(Source:UNIOVI)

entry be forbidden without PPE). The zone 2, area corresponds to the place with the potential to reach the environmental values, points $7,8,11,14,15$, and 16 ; this area must be closed to the general public, and the use of PPE should be advised within it. Zone 3 has low mercury concentration in the air (less than 10\% TLV-TWA) and could be open to the general public without PPE.

An increase in mercury levels was observed relating to the temperature (or soil temperature). It is recommended works be avoided in Zone 1 during the hottest days of the year or long periods of work are avoided in the area. During cold days, there is not a real problem with the release of gaseous mercury in the area. However, as occurred during hot days, it is recommended that workers spend the shortest amount of time possible in the area where rubble is stored. The influence of temperature upon gaseous mercury emissions has been confirmed the studies by Gustin et al. [15].

\subsection{Arsenic and mercury particulates}

The airborne arsenic and mercury particulate concentrations for each sample were calculated from the mass measured by the volume of air sampled. Table 4 shows the arsenic and mercury concentrations in air and soils.

Regarding the soil arsenic in industrial sites, the International Legislation established the intervention level at 300 ppm [30] and 100 ppm for non-industrial activities. According to the government of the Principality of Asturias, Risk-Based Soil Screening Levels (RBSSLs from March 20 , 2014) [31] established a limit of 200 ppm for industrial activities and $40 \mathrm{ppm}$ for non-industrial activities. As shown in Tables 2 and 4, the Soterraña soils are very contaminated. All the airborne arsenic values are under the TLV-TWA values, the fourth arsenic measurement taken in windy conditions is around 10 times bigger than the other measurements. It is most likely particles from the soil were elevated by the wind.

According to the UNE EN 689:2019+AC:2019 [35], there were at least three measurements with values less than $10 \%$ of TLV-TWA, therefore it can be concluded that the work exposure is under the legislation limits. All four measurements for As are less than 10\% of the TLV-TWA. Nevertheless, when any of the chemicals analyzed is a carcinogen, the levels must be as low as technically possible [36]. Arsenic is a carcinogen, and the work in the area must be considered with protective equipment, Personal Protective Equipment (PPE), and other measures to minimize dust. Regarding the mercury particulates in the air, the four measurements were lower than the laboratory limit of detection (LOD) $(0.1 \mu \mathrm{g})$. The mercury in the particulate samples can be considered negligible.

\section{Conclusions}

The Soterreña mine site soil is very contaminated, and a restoration plan is necessary to ensure a healthy environment for the local populations. A significant part of the La Soterraña decommissioned $\mathrm{Hg}$ mine showed gaseous $\mathrm{Hg}$ and particulate As levels that are not problematic for workers who carry out their work for periods of up to $8 \mathrm{~h}$.

Table 4 Contamination levels in air and soil

\begin{tabular}{|c|c|c|c|c|c|c|}
\hline \multirow[t]{3}{*}{ Date } & \multirow[t]{3}{*}{ Location } & \multicolumn{2}{|l|}{ Mercury } & \multicolumn{2}{|l|}{ Arsenic } & \multirow[t]{3}{*}{ References } \\
\hline & & $\begin{array}{l}\text { Particulate air } \\
\text { leves }\end{array}$ & Soil & $\begin{array}{l}\text { Particulate air } \\
\text { levels }\end{array}$ & Soil & \\
\hline & & $\mu g / m^{3}$ & (ppm) & $\mu \mathrm{g} / \mathrm{m}^{3}$ & (ppm) & \\
\hline 04/08/2020 & 10) Metallurgy furnace debris (rubble) & $<0.08$ & 34,691 & 0.033 & 54,801 & {$[32]$} \\
\hline $04 / 08 / 2020$ & 11) Metallurgy furnace previous location & $<0.08$ & 400 & 0.033 & 6000 & [34] \\
\hline 04/08/2020 & 21) Furnace slap heap & $<0.08$ & 1330 & 0.059 & 10,800 & [33] \\
\hline $24 / 09 / 2020$ & 10) Metallurgy furnace debris (rubble) ${ }^{a}$ & $<0.45$ & 34,691 & 0.54 & 54,801 & {$[32]$} \\
\hline
\end{tabular}

aSample taken on windy conditions 
(a) Regarding mercury and particulate arsenic air contamination

The air pollution levels in the Soterraña site are under legal legislation levels, apart from in the rubble area for gaseous mercury zone 1 (points 9,10 and 17, Fig. 3); the arsenic and mercury particle samples collected with the IOM sampler are less than $10 \%$ of the TLV-TWA limits.

(b) Regarding workers' protections

Only, zone 1 has the potential to reach mercury TLVTWA limits when working an $8 \mathrm{~h} /$ day in the area. It is recommended that workers avoid working the full shift in the area, and avoid working during the hottest hours of the day and on the hottest days of the year.

In the same way, arsenic is a carcinogen substance, and it is mandatory to keep the levels as low as technically possible; the use of PPE is highly recommended.

The recommended PPE for workers in the mine is a half facepiece reusable mask with FFP3 and mercury vapour and chlorine gas filter, disposable overalls, hard hat, safety boots, and hi-vis vest. It is imperative that workers do not eat, drink or smoke in zones 1 or 2.

An increase in the arsenic levels was observed relating to the wind; it is recommended that workers stay away from the area in the presence of strong winds or that health and safety measures should be improved.

(c) Regarding risks to the general public.

There is no risk of exposure to airborne $\mathrm{Hg}$ or As particulates for cyclists taking part in competitions or the population of the nearby villages from works in the mine area. The main efforts in the project Subproducts4life must be focused on minimizing or avoiding surface water contamination.

If the rubble is dry, it is recommended that water be applied before starting any work, to minimize dust. All the cleaning operations for the site or equipment must be carried out in wet conditions to avoid the suspension dust in the air.

The argillaceous minerals present in the dumps may be responsible for the low presence of particulate arsenic and mercury particulates in the air. Even in windy conditions, this must be taken into account for studies in other mines.

Acknowledgements The authors would like to thank the program LIFE of the European Commission the for the funding received for the project SUBproducts4LIFE. Authors also would like to thank the collaboration of the the institutions and private companies that participated in the project: Biosfera consultoría Medioambiental (BIOSFERA), Escorias y Derivados (EDERSA), Global Service (GService), Hidroeléctrica del Cantábrico (EDP), Instituto Asturiano de
Prevención de Riesgos Laborales (IAPRL), Recuperación y Renovación (R\&R) and Universidad de Oviedo (UNIOVI). Finally, the collaboration of sponsors Arcelor Mittal, Ingeniería de Montajes Norte SA (IMSA), Asturbelga de Minas, and Lena Council, and the Instituto Nacional de Silicosis (INS) is also greatly appreciated.

Funding The funding was provided by European Commission, LIFE program, project SUBproducts4LIFE (ref. LIFE16 ENV/ES/000481).

\section{Declarations}

Conflict of interest On behalf of all authors, the corresponding author states that there is no conflict of interest.

Open Access This article is licensed under a Creative Commons Attribution 4.0 International License, which permits use, sharing, adaptation, distribution and reproduction in any medium or format, as long as you give appropriate credit to the original author(s) and the source, provide a link to the Creative Commons licence, and indicate if changes were made. The images or other third party material in this article are included in the article's Creative Commons licence, unless indicated otherwise in a credit line to the material. If material is not included in the article's Creative Commons licence and your intended use is not permitted by statutory regulation or exceeds the permitted use, you will need to obtain permission directly from the copyright holder. To view a copy of this licence, visit http://creativecommons. org/licenses/by/4.0/.

\section{References}

1. Coelho PCS, Teixeira JPF, Gonçalves ONBSM (2011) Mining activities: health impacts. In: Nriagu JO (eds) Encyclopedia of environmental health. Elsevier, Burlington, pp 788-802. ISBN 978-0-444-52272-6

2. Hylander LD, Meili M (2005) The rise and fall of mercury: converting a resource to refuse after 500 years of mining and pollution. Crit Rev Environ Sci Technol 35:1-36. https://doi.org/10.1080/ 10643380490492485

3. Loredo J, Ordoñez A, Galán MP (2005) Surface water monitoring in abandoned mercury mine sites in Asturias (Spain): comparative studies. In: 9th International mine water congress

4. Garcia-Ordiales E, Covelli S, Rico JM, Roqueñí N, Fontolan G, FlorBlanco G, Cienfuegos P, Loredo J (2018) Occurrence and Speciation of arsenic and mercury in estuarine sediments affected by mining activities (Asturias, Northern Spain). Chemosphere 198:281-289. https://doi.org/10.1016/j.chemosphere.2018.01. 146

5. Fernández B, Lara L, Menendez-Aguado J, Ayala J, GarcíaGonzález N, Salgado L, Colina A, Gallego JL (2020) A multifaceted, environmental forensic characterization of a paradigmatic brownfield polluted by hazardous waste containing $\mathrm{Hg}$, As, PAHs and dioxins. Sci Total Environ 726:138546. https://doi. org/10.1016/j.scitotenv.2020.138546

6. Boente C, Salgado L, Romero Macias E, Colina A, López-Sánchez C, Gallego JL (2020) Correlation between geochemical and multispectral patterns in an area severely contaminated by former Hg-As mining. Int J Geo-Inf. https://doi.org/10.3390/ijgi9120739

7. Loredo J, Soto J, Alvarez R, Ordóñez A (2007) Atmospheric monitoring at abandoned mercury mine sites in Asturias (NW Spain). Environ Monit Assess 130:201-214. https://doi.org/10.1007/ s10661-006-9389-0 
8. Smith AH, Ercumen A, Yuan Y, Steinmaus CM (2009) Increased lung cancer risks are similar whether arsenic is ingested or inhaled. J Expo Sci Environ Epidemiol 19:343-348. https://doi. org/10.1038/jes.2008.73

9. Fryer $P$, Harrison $P$ (2000) Exposure to airborne arsenic: a review of recent epidemiological research. Epidemiology 11:S67

10. Palma-Lara I, Martínez-Castillo M, Quintana-Pérez JC, ArellanoMendoza MG, Tamay-Cach F, Valenzuela-Limón OL, GarcíaMontalvo EA, Hernández-Zavala A (2020) Arsenic exposure: a public health problem leading to several cancers. Regul Toxicol Pharmacol RTP 110:104539. https://doi.org/10.1016/j.yrtph. 2019.104539

11. Saha JC, Dikshit AK, Bandyopadhyay M, Saha KC (1999) A review of arsenic poisoning and its effects on human health. Crit Rev Environ Sci Technol 29:281-313. https://doi.org/10.1080/10643 389991259227

12. WHO (2017) Mercury and health. World Health Organization. https://www.who.int/news-room/fact-sheets/detail/mercuryand-health. Accessed 1 Feb 2021

13. US EPA (2021) Basic information about Mercury. United States Environmental Protection Agency. https://www.epa.gov/mercu ry/basic-information-about-mercury. Accessed 27 Jan 2021

14. Saturday A (2018) Mercury and its associated impacts on environment and human health: a review. J Environ Health Sci. https://doi.org/10.15436/2378-6841.18.1906

15. Gustin SM, Coolbaugh M, Engle M, Fitzgerald B, Keislar R, Lindberg S, Nacht D, Quashnick J, Rytuba J, Sladek C et al (2003) Atmospheric mercury emissions from mine wastes and surrounding geologically enriched terrains. Environ Geol. https:// doi.org/10.1007/S00254-002-0630-Z

16. Ordóñez MA, Silva V, Galán P, Loredo J, Rucandio I (2013) Arsenic input into the Catchment of the River Caudal (Northwestern Spain) from abandoned $\mathrm{Hg}$ mining works: effect on water quality. Environ Geochem Health. https://doi.org/10.1007/ s10653-013-9566-3

17. Larios R, Fernández-Martínez R, Silva V, Loredo J, Rucandio I (2012) Arsenic contamination and speciation in surrounding waters of three old cinnabar mines. J Environ Monit JEM 14:531-542. https://doi.org/10.1039/c1em10684h

18. Hagan N, Robins N, Hsu-Kim H, Halabi S, Morris M, Woodall G, Zhang T, Bacon A, Richter DDB, Vandenberg J (2011) Estimating historical atmospheric mercury concentrations from silver mining and their legacies in present-day surface soil in Potosí, Bolivia. Atmos Environ 45:7619-7626. https://doi.org/10.1016/j. atmosenv.2010.10.009

19. EPA (2009) Graphical arrays of chemical-specific health effect reference values for inhalation exposures final report U.S. Environmental Protection Agency. https://cfpub.epa.gov/ncea/risk/ recordisplay.cfm?deid=211003. Accessed 27 Jan 2021

20. NIOSH (2007) NIOSH pocket guide to chemical hazards. https:// www.cdc.gov/niosh/docs/2005-149/pdfs/2005-149.pdf. Accessed 27 Jan 2021

21. OEHHA (2019) Acute, 8-hour and chronic reference exposure level (REL) summary. California Office of Environmental Health Hazard Assessment. https://oehha.ca.gov/air/general-info/ oehha-acute-8-hour-and-chronic-reference-exposure-levelrel-summary. Accessed 22 July 2021

22. EPA (1995) Guidance for risk characterization. U.S. Environmental Protection Agency. https://www.epa.gov/sites/default/files/ 2015-11/documents/guidance-risk-characterization-feb1995. pdf. Accessed 22 July 2021

23. INSST (2021) Límites de Exposición Profesional Para Agentes Químicos En España. Instituto Nacional de Seguridad e Higiene en el trabajo. https://www.insst.es/documentacion/catalogode-publicaciones/limites-de-exposicion-profesional-para-agent es-quimicos. Accessed 22 July 2021
24. WHO (2000) Air quality guidelines for Europe. World Health Organization. https://www.euro.who.int/_data/assets/pdf file/0005/74732/E71922.pdf. Accessed 22 July 2021

25. Ministerio de la presidencia (2011) Royal Decree 102/2011, of 28 January on the improvement of air quality. https://www.boe.es/ boe/dias/2011/01/29/pdfs/BOE-A-2011-1645.pdf. Accessed 22 July 2021

26. European Committee for Standardization (1993) CEN. EN 481 Workplace atmospheres: size fraction definitions for measurement of airborne particles. https://tienda.aenor.com/normabsi-bs-en-481-1993-bs-6069-3-5-1993-000000000000313177. Accessed 22 July 2021

27. HSE (2014) MDHS14/4 general methods for sampling and gravimetric analysis of respirable, thoracic and inhalable aerosols. Health and Safety Executive. https://www.hse.gov.uk/pubns/ mdhs/pdfs/mdhs14-4.pdf. Accessed 22 July 2021

28. Casella (2019) Casella air sampling handbook. https://www. casellasolutions.com/content/dam/casella/ecommerce/docum ents/handbooks/air-sampling-handbook/AirSamplingSolutions Handbook.pdf. Accessed 22 July 2021

29. Nagl C, Spangl W, Buxbaum I (2019) Sampling points for air quality; representativeness and comparability of measurement in accordance with directive 2008/50/EC on ambient air quality and cleaner air for Europe. Luxembourg

30. CONSEJERÍA DE MEDIO AMBIENTE, JUNTA DE ANDALUCIA (1999) Los Criterios y Estándares Para Declarar Un Suelo Contaminado En Andalucía y La Metodología y Técnicas de Toma de Muestra y Análisis Para Su Investigación. https://www.juntadeandalucia.es/sites/default/files/2020-03/1337166623inorganicos.pdf. Accessed 22 July 2021

31. CONSEJERÍA DE MEDIO AMBIENTE, PRINCIPADO DE ASTURIAS (2014). Resolución de 20 de Marzo de 2014, de La Consejería de Fomento, Ordenación Del Territorio y Medio Ambiente, Por La Que Se Establecen Los Niveles Genéricos de Referencia Para Metales Pesados En Suelos Del Principado de Asturias. https:// sede.asturias.es/bopa/2014/04/21/2014-06617.pdf. Accessed 22 July 2021

32. Ayala J, Fernández B (2019) Industrial waste materials as adsorbents for the removal of as and other toxic elements from an abandoned mine spoil heap leachate: a case study in Asturias. J Hazard Mater 384:121446. https://doi.org/10.1016/j.jhazmat. 2019.121446

33. Larios R, Fernández-Martínez R, Alvarez R, Rucandio I (2012) Arsenic pollution and fractionation in sediments and mine waste samples from different mine sites. Sci Total Environ 431:426-435. https://doi.org/10.1016/j.scitotenv.2012.04.057

34. Ordóñez MA, Alvarez R, Charlesworth S, De Miguel E, Loredo J (2010) Risk assessment of soils contaminated by mercury mining, Northern Spain. J Environ Monit JEM 13:128-136. https:// doi.org/10.1039/c0em00132e

35. European Standards UNE EN 689:2019+AC:2019 workplace exposure-measurement of exposure by inhalation to chemical agents-strategy for testing compliance with occupational exposure limit values 2019

36. Ministerio de la Presidencia (1997). Royal Decree 665/1997 of May 12, on the protection of workers from the risks related to exposure to carcinogens at work. https://boe.es/buscar/pdf/ 1997/BOE-A-1997-11145-consolidado.pdf. Accessed 22 July 2021

Publisher's Note Springer Nature remains neutral with regard to jurisdictional claims in published maps and institutional affiliations. 